\title{
The assessment of glycemic control and renal function in ischemic heart patients
}

\author{
Ehsan Hassan Taha Al-Dabbagh* , Professor Akram J. Ahmad** \\ ${ }^{\star \star}$ Department of Biochemistry, College of Medicine, University of Mosul ,**Department of \\ Biochemistry (retired), College of Medicine, University of Mosul, Mosul, Iraq . \\ Correspondence: inssanht@uomosul.edu.iq
}

(Ann Coll Med Mosul 2020; 42 (1):27-34).

Received: $16^{\text {th }}$ June 2020; Accepted: $13^{\text {th }}$ July 2020.

\section{ABSTRACT}

Background: Ischemic heart diseases are considered as the leading cause of death throughout the world and a major cause of hospital admissions. Diabetes mellitus together with hypertension are among the modifiable risk factors.

Aims of the study: To assess the glycemic control and renal function tests of patients with ischemic heart diseases.

Methods: Fasting blood samples were obtained from seventy one cases of ischemic heart disease who were admitted to cardiac care unit, mean age 60.9 years old, sera were used to measure urea, creatinine and glucose by enzymatic colorimetric method while blood with anticoagulant used for glycated hemoglobin measurement by ion exchange resin quantitative colorimetric determination and urine samples were obtained for analysis of protein/creatinine ratio by turbidimetric method. Measurement of micro albumin in urine is based on immunoassay with flouresence detection. Statistics included t-test and linear regression.

Results: There was a significant difference between diabetics and non-diabetics in regard to fasting plasma glucose, glycated hemoglobin and protein /creatinine ratio. The major difference between patients with angina pectoris and those with acute myocardial infarction was that the latter had significantly higher fasting plasma glucose.

Conclusion and recommendation: Ischemic heart disease patients have badly controlled hyperglycemia and some degree of renal impairment. Protein / creatinine ratio and/or micro albuminuria should be introduced in the list of biochemical tests requested for these patients.

Key words: ischemic heart disease, microalbuminuria, glycemic control, renal function

$$
\begin{aligned}
& \text { تقييم السيطرة السكرية ووظائف الكلية عند مرضى نقص التروية القلبية }
\end{aligned}
$$

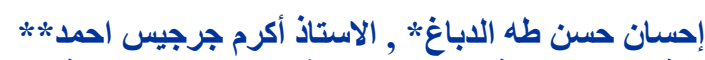

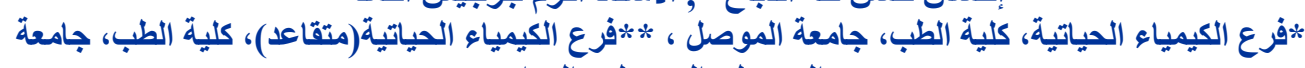

$$
\begin{aligned}
& \text { الموصل، الموصل ، العراق الكياء }
\end{aligned}
$$

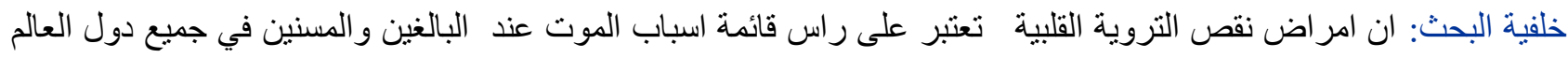

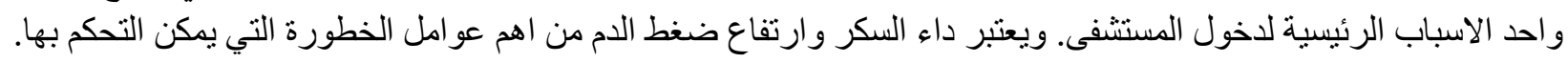

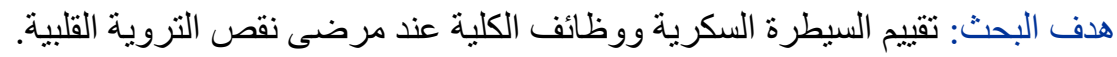
طريقة البحث: شملت هذه الدر اسة مصول والئة واحد وسبعون مريضا بنقص التروية القلبية ، متوسط اعمار هم 60,9 سنة، من الذين

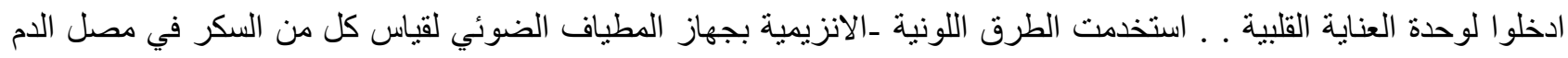

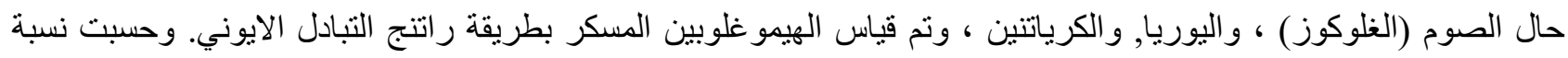

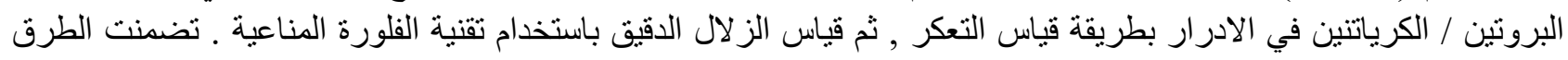

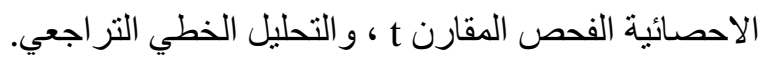


النتائج: لوحظ ان المرضى المصابين بداء السكري كان لايهم مستوى عالي ومعتبر في كل من السكر حال الصوم ، الهيمو غلوبين

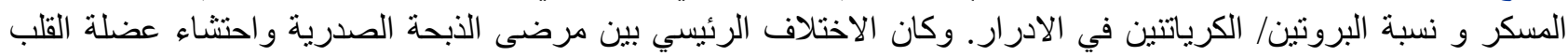

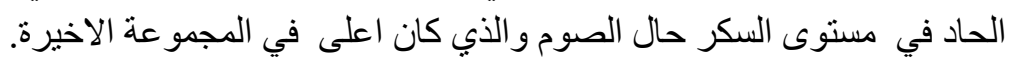

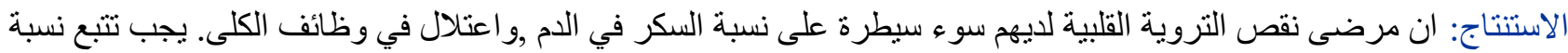

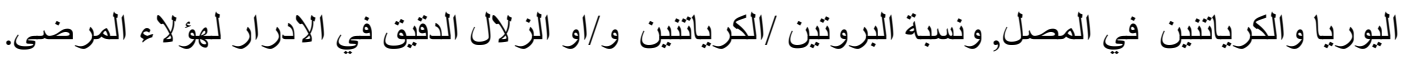

الكلمات المفتاحية: نقص التروية القلبية, الز لال الدقيق في البول, السيطرة السكرية, وظائف الكلى .

\section{INTRODUCTION}

Tr he word ischemia is also spelled as ischaemia or ischæmia, (from Greek language ıбXaınía, ischaimía; isch- root denoting a restriction or thinning or to grow thin/lean, haema; blood) is defined as a restriction in blood supply to tissues, causing a shortage of oxygen and glucose needed for cellular metabolism ${ }^{1}$. In the highly aerobic tissues of the heart and brain, irreversible damage can occur in as little as 3-4 minutes $^{2}$.

Ischemic heart diseases ( IHD) is considered as the leading cause of death throughout the world and a major cause of hospital admissions. The World Health Organization $(\mathrm{WHO})$ estimated that $12.2 \%$ of worldwide deaths were from IHD; with it being the leading cause of death in high or middle income countries and second only to lower respiratory tract infections in low- income countries. Worldwide more than 7 million people have IHD a year ${ }^{3}$.

The most common triggering event is the disruption of an atherosclerotic plaque in the inner lining of coronary artery, which leads to a clotting cascade and sometimes resulting in total occlusion of the artery ${ }^{4}$.Ischemic heart diseases refer to a spectrum of diseases including the following:

Angina pectoris, a chest pain on exertion, in cold weather or emotional stress, feel like tightness, heavy pressure or squeezing pain. It is relieved by rest. Acute myocardial infarction AMI or "heart attack", with more severe chest pain which is described as agonizing , stabbing associated with sweating and sometimes vomiting , unrelieved by rest. And sudden death even without chest pain which is not uncommon ${ }^{5}$.

Diabetes mellitus DM together with hypertension are among the most important modifiable risk factors for IHD. Hypertension is regarded as an important public health challenge, because of the associated morbidity and mortality ${ }^{6}$.
Worldwide adults with DM have an annual mortality rate of $5.4 \%$ - twice that of non diabeticsand their life expectancy is decreased by five to ten years, this increased mortality is mainly due to atherosclerotic vascular complication ${ }^{7}$.

Glycemic control is monitored in hospital by testing blood glucose level either upon fasting or random occasion and glycated hemoglobin measurement ${ }^{8}$ The goal is to reduce fasting plasma glucose FPG to at least below $7.8 \mathrm{mmol} / \mathrm{L}$ but preferably below $6.1 \mathrm{mmol} / \mathrm{L}^{9}$, and most clinical diabetes organizations worldwide now recommend either $6.5 \% \mathrm{HbA} 1 \mathrm{c}$ as a target for glycemic control $^{10}$.

Estimation of serum urea and creatinine is usually regarded as the first line investigation of renal excretory functions ${ }^{11}$, while Protein excretion in urine normally not exceeds $150-300 \mathrm{mg}$ /24 hr., figures greater than $300 \mathrm{mg} / 24 \mathrm{hr}$., is considered macroalbuminuria ${ }^{12}$. increasing microalbuminuria during the first 48 hours after admission to an intensive care unit predicts elevated risk for acute respiratory failure, multiple organ failure, and overall mortality ${ }^{13}$

This study to assess the glycemic control and renal function tests of IHD patients admitted to cardiac care unit (CCU) and to find out the differences between patients with angina pectoris and $\mathrm{AMI}$ in regard to biochemical markers that refers to glycemic control and renal function .

\section{Subjects, Material and Methods}

The study involved seventy one cases of IHD consisting of (28) females and(43) males, age range between 35-78 with mean age of 60.9 years old, were admitted newly to CCU in Ibn-Sina teaching hospital ,in Mosul, during a period extended from the $25^{\text {th }}$ of April and ended on the $5^{\text {th }}$ of June 2011.Ischemic heart disease were confirmed according to the WHO criteria, the diagnosis of $\mathrm{AMI}$ is established when there is 
typical chest pain suggestive of myocardial ischemia, ST-segment changes or the development of new $Q$ waves on the ECG, and abnormal cardiac enzymes detectable in the peripheral blood ${ }^{14}$. Patients were classified accordingly to those with angina $(n=42)$ and to those with AMI ( $n=29)$ subjects. The diabetics $(\mathrm{n}=28)$ and hypertensive patients $(\mathrm{n}=37)$.

Fasting blood samples were obtained at 8-9 a.m., serum separated from plain disposable tube was used to measure urea , creatinine and fasting plasma glucose (FPG), by enzymatic colorimetric method specific for each parameter ${ }^{15-17}$,whole blood in (EDTA) tube used for glycated hemoglobin( $\mathrm{HbA1c})$ measurement by ion exchange resin quantitative colorimetric determination ${ }^{18,19}$.

Clean catch midstream urine samples were obtained for analysis of protein/creatinine ratio $(\mathrm{P} / \mathrm{C}$ ratio), Protein is measured in $(\mu \mathrm{g} . / \mathrm{ml})$ by turbidimetric method ${ }^{20} \mathrm{P} / \mathrm{C}$ ratio $(\mathrm{mg} . / \mathrm{mmol})$ is calculated simply by dividing urine protein on urine creatinine with adjustment of units according to the following formula.

Protein excretion $=\left(\right.$ Urine protein $\left.{ }^{*} 0.088\right) \div$ Urine creatinine ${ }^{21}$

Measurement of microalbumin in urine is based on sandwich immunoassay method with final flouresence detection ${ }^{22,23}$ using $i$-chroma system, Boditech medical incorporation, Korea. Results of $i$-chroma is displayed as $\mathrm{mg} . / \mathrm{L}$

\section{Statistical Analysis}

The following statistical methods were used for the analysis of data.

Standard statistical methods for mean, standard deviation (SD).

Linear regression analysis (r) and Unpaired student t-test was used to compare results of various biochemical parameters among subjects of different groups

All values quoted as the mean $\pm S D$. Differences between observation were considered significant at $p \leq 0.05 .{ }^{24,25}$

\section{RESULTS}

The mean \pm SD of age and different biochemical parameters are shown in table (1).

Those who had AMl constituted (40.8\%), patients with angina pectoris were $(59.2 \%)$, male $(60.6 \%)$, female(39.4\%) i.e. male: female ratio
(1.5:1). Diabetic patients constituted (39\%), while hypertensive patients were( $52 \%$ ).

Table (1) Means $\pm S D$ of age and different parameters for all patients

\begin{tabular}{|l|l|}
\hline Parameters & mean \pm SD \\
\hline Age (years) & $60.930 \pm 10.769$ \\
\hline FPG $(\mathrm{mmol} / \mathrm{L})$ & $8.141 \pm 4.872$ \\
\hline HbA1c $\%$ & $6.520 \pm 1.673$ \\
\hline S.urea $(\mathrm{mmol} / \mathrm{L})$ & $7.804 \pm 4.141$ \\
\hline S.creatinine $(\mu \mathrm{mol} / \mathrm{L})$ & $127.994 \pm 89.496$ \\
\hline P/C ratio $(\mathrm{mg} . / \mathrm{mmol})$ & $51.050 \pm 83.227$ \\
\hline & \\
Microalbuminuria $(\mathrm{mg} . / \mathrm{L})$ & $110.150 \pm 122.675$ \\
\hline
\end{tabular}

Table (2) Comparison of different biochemical parameters in both sexes .

\begin{tabular}{|c|c|c|c|}
\hline Parameters & $\begin{array}{l}\text { se } \\
x\end{array}$ & mean $\pm S D$ & $\begin{array}{l}p- \\
\text { valu } \\
e\end{array}$ \\
\hline$\overline{F P G}(\mathrm{mmol} / \mathrm{L})$ & $\begin{array}{l}\mathrm{f} \\
\mathrm{m}\end{array}$ & $\begin{array}{c}9.007 \pm 5.176 \\
7.577 \pm 4.638\end{array}$ & NS \\
\hline $\mathrm{HbA1c} \%$ & $\begin{array}{l}f \\
m\end{array}$ & $\begin{array}{l}6.714 \pm 1.692 \\
6.393 \pm 1.667\end{array}$ & NS \\
\hline Urea ( $\mathrm{mmol} / \mathrm{L})$ & $\begin{array}{l}f \\
m\end{array}$ & $\begin{array}{l}8.346 \pm 4.826 \\
7.451 \pm 3.645\end{array}$ & NS \\
\hline Creatinine $(\mu \mathrm{mol} / \mathrm{L})$ & $\begin{array}{l}f \\
m\end{array}$ & $\begin{array}{l}113.679 \pm 63.29 \\
6 \\
137.316 \pm 102.6 \\
71\end{array}$ & NS \\
\hline $\mathrm{P} / \mathrm{C}$ ratio $(\mathrm{mg} . / \mathrm{mmol})$ & $\begin{array}{l}f \\
m\end{array}$ & $\begin{array}{l}40.90 \pm 28.751 \\
57.05 \pm 102.671\end{array}$ & NS \\
\hline $\begin{array}{l}\text { Microalbuminuria }(\mathrm{m} \\
\mathrm{g} / \mathrm{L})\end{array}$ & $\begin{array}{l}f \\
m\end{array}$ & $\begin{array}{l}70.745 \pm 95.559 \\
132.963 \pm 131.7 \\
45\end{array}$ & NS \\
\hline
\end{tabular}

$f$ : female , $\mathrm{m}:$ male, $p$ - value $\geq 0.05$ not significant (NS)

The patients were grouped in table (3) into those with angina $(n=42,59 \%)$, and those with AMI $(n=29,41 \%)$, there was a significant difference in FPG. 
Table (3) Comparison of different biochemical parameters in angina patients to myocardial

\begin{tabular}{|l|l|l|l|}
\hline Parameters & $\begin{array}{l}\text { Clinical } \\
\text { conditio } \\
\mathrm{n}\end{array}$ & mean \pm SD & $\begin{array}{l}p \text { - } \\
\text { value }\end{array}$ \\
\hline FPG mmol/L & 1 & $\begin{array}{l}7.114 \pm 3.687 \\
9.628 \pm 5.963\end{array}$ & 0.032 \\
\hline HbA1c \% & 1 & $\begin{array}{l}6.421 \pm 1.635 \\
6.662 \pm 1.745\end{array}$ & NS \\
\hline Urea( mmol/L) & 2 & $\begin{array}{l}7.921 \pm 4.983 \\
7.634 \pm 2.542\end{array}$ & NS \\
\hline $\begin{array}{l}\text { Creatinine( } \mu \mathrm{mol} / \mathrm{L} \\
\text { ) }\end{array}$ & 1 & $\begin{array}{l}122.781 \pm 98.831 \\
135.545 \pm 74.977\end{array}$ & $\mathrm{NS}$ \\
\hline $\begin{array}{l}\text { P/C } \\
\text { ratio(mg./mmol) }\end{array}$ & 2 & $\begin{array}{l}57.66 \pm 102.848 \\
40.60 \pm 34.182\end{array}$ & NS \\
\hline $\begin{array}{l}\text { Microalbuminuria( } \\
\text { mg/L) }\end{array}$ & 1 & $96.778 \pm 113.581$ & NS \\
\hline
\end{tabular}

infarction patients.

$1=$ angina pectoris $2=\mathrm{AMI}$

The biochemical markers of diabetic patients $(\mathrm{n}=28,39 \%)$, were studied and compared to nondiabetics $(n=43,61 \%)$, there were significant differences in FPG , HbA1c, P/C ratio. Table (4).

Table(4). Comparison of different biochemical parameters in diabetics to non-diabetics.

\begin{tabular}{|l|l|l|l|}
\hline parameters & $\begin{array}{l}\text { Clinical } \\
\text { condition }\end{array}$ & mean \pm SD & $\begin{array}{l}p \text { - } \\
\text { value }\end{array}$ \\
\hline FPG (mmol/L) & $\begin{array}{l}\text { Non- } \\
\text { diabetic } \\
\text { diabetic }\end{array}$ & $\begin{array}{l}5.514 \pm 1.516 \\
12.175 \pm 5.489\end{array}$ & 0.000 \\
\hline HbA1c\% & $\begin{array}{l}\text { Non- } \\
\text { diabetic } \\
\text { diabetic }\end{array}$ & $\begin{array}{l}5.593 \pm 1.131 \\
7.943 \pm 1.340\end{array}$ & 0.000 \\
\hline Urea( mmol/L) & $\begin{array}{l}\text { Non- } \\
\text { diabetic } \\
\text { diabetic }\end{array}$ & $\begin{array}{l}7.070 \pm 1.131 \\
8.932 \pm 1.340\end{array}$ & NS \\
\hline $\begin{array}{l}\text { Creatinine } \\
(\mu \mathrm{mol} / \mathrm{L})\end{array}$ & $\begin{array}{l}\text { Non- } \\
\text { diabetic } \\
\text { diabetic }\end{array}$ & $\begin{array}{l}120.109 \pm 3.025 \\
140.104 \pm 5.300\end{array}$ & NS \\
\hline $\begin{array}{l}\text { P/C } \\
(\mathrm{mg} . / \mathrm{mmol})\end{array}$ & $\begin{array}{l}\text { Non- } \\
\text { diabetic } \\
\text { diabetic }\end{array}$ & $\begin{array}{l}73.69 \pm 28.563 \\
76.75 \pm 123.405\end{array}$ & 0.045 \\
\hline $\begin{array}{l}\text { Microalbuminuria } \\
(\mathrm{mg} / \mathrm{L})\end{array}$ & $\begin{array}{l}\text { Non- } \\
\text { diabetic } \\
\text { diabetic }\end{array}$ & $\begin{array}{l}90.972 \pm 109.980 \\
123.849 \pm 130.818\end{array}$ & NS \\
\hline
\end{tabular}

There was no significant difference between the patients who were admitted for the first time $(n=$ 34 ) and those who had previous admission to CCU $(n=37)$. Table (6).

Table(5) Comparison of different biochemical parameters in hypertensive versus nonhypertensive

\begin{tabular}{|c|c|c|c|}
\hline parameters & $\begin{array}{l}\text { Clinical } \\
\text { condition }\end{array}$ & mean $\pm S D$ & $\begin{array}{r}p- \\
\text { valu } \\
\mathrm{e}\end{array}$ \\
\hline $\mathrm{FPG}(\mathrm{mmol} / \mathrm{L})$ & $\begin{array}{l}\text { Non- } \\
\text { hypertensive } \\
\text { Hypertensive }\end{array}$ & $\begin{array}{l}7.574 \pm 4.646 \\
8.662 \pm 5.078\end{array}$ & NS \\
\hline $\mathrm{HbA} 1 \mathrm{c} \%$ & $\begin{array}{l}\text { Non- } \\
\text { hypertensive } \\
\text { Hypertensive }\end{array}$ & $\begin{array}{l}6.194 \pm 1.714 \\
6.819 \pm 1.599\end{array}$ & NS \\
\hline Urea $(\mathrm{mmol} / \mathrm{L})$ & $\begin{array}{l}\text { Non- } \\
\text { hypertensive } \\
\text { hypertensive }\end{array}$ & $\begin{array}{r}7.215 \pm 2.762 \\
8.346 \pm 5.071\end{array}$ & NS \\
\hline $\begin{array}{l}\text { Creatinine } \\
(\mu \mathrm{mol} / \mathrm{L})\end{array}$ & $\begin{array}{l}\text { Non- } \\
\text { hypertensive } \\
\text { hypertensive }\end{array}$ & $\begin{array}{l}124.044 \pm 73.85 \\
4 \\
131.624 \pm 102.6 \\
94\end{array}$ & NS \\
\hline $\begin{array}{l}\mathrm{P} / \mathrm{C} \quad \text { ratio } \\
(\mathrm{mg} . / \mathrm{mmol})\end{array}$ & $\begin{array}{l}\text { Non- } \\
\text { hypertensive } \\
\text { hypertensive }\end{array}$ & $\begin{array}{l}42.03 \pm 43.159 \\
59.52 \pm 108.326\end{array}$ & NS \\
\hline $\begin{array}{l}\text { Microalbumin } \\
\text { uria (mg/L) }\end{array}$ & $\begin{array}{l}\text { Non- } \\
\text { hypertensive } \\
\text { hypertensive }\end{array}$ & $\begin{array}{l}102.179 \pm 117.2 \\
41 \\
117.606 \pm 129.0 \\
30\end{array}$ & NS \\
\hline
\end{tabular}


Table(6) Comparison between patients with negative history of IHD (-ve) with positive history of IHD(+ve).

\begin{tabular}{|c|c|c|c|}
\hline Parameters & $\begin{array}{l}\text { Previous } \\
\text { admission }\end{array}$ & mean \pm SD & $\begin{array}{l}p- \\
\text { value }\end{array}$ \\
\hline $\mathrm{FPG}(\mathrm{mmol} / \mathrm{L})$ & $\begin{array}{l}-v e \\
+v e\end{array}$ & $\begin{array}{l}8.868 \pm 5.543 \\
7.473 \pm 4.127\end{array}$ & NS \\
\hline $\mathrm{HbA} 1 \mathrm{c} \%$ & $\begin{array}{l}-v e \\
+v e\end{array}$ & $\begin{array}{l}6.485 \pm 1.855 \\
6.551 \pm 1.511\end{array}$ & NS \\
\hline Urea (mmol/L) & $\begin{array}{l}-\mathrm{ve} \\
+\mathrm{ve}\end{array}$ & $\begin{array}{l}7.444 \pm 2.681 \\
8.135 \pm 5.150\end{array}$ & NS \\
\hline $\begin{array}{l}\text { Creatinine } \\
(\mu \mathrm{mol} / \mathrm{L})\end{array}$ & $\begin{array}{l}-v e \\
+v e\end{array}$ & $\begin{array}{l}120.362 \pm 70.923 \\
135.008 \pm 104.200\end{array}$ & NS \\
\hline $\begin{array}{ll}\mathrm{P} / \mathrm{C} & \text { ratio } \\
(\mathrm{mg} . / \mathrm{mmol}) & \\
\end{array}$ & $\begin{array}{l}-v e \\
+v e\end{array}$ & $\begin{array}{l}37.04 \pm 33.594 \\
63.37 \pm 109.004 \\
\end{array}$ & NS \\
\hline $\begin{array}{l}\text { Microalbuminuria } \\
\text { (mg/L) }\end{array}$ & $\begin{array}{l}-\mathrm{ve} \\
+\mathrm{ve}\end{array}$ & $\begin{array}{l}102.996 \pm 118.905 \\
116.409 \pm 127.442\end{array}$ & NS \\
\hline
\end{tabular}

Figures of correlation between different biochemical parameters are demonstrated below :

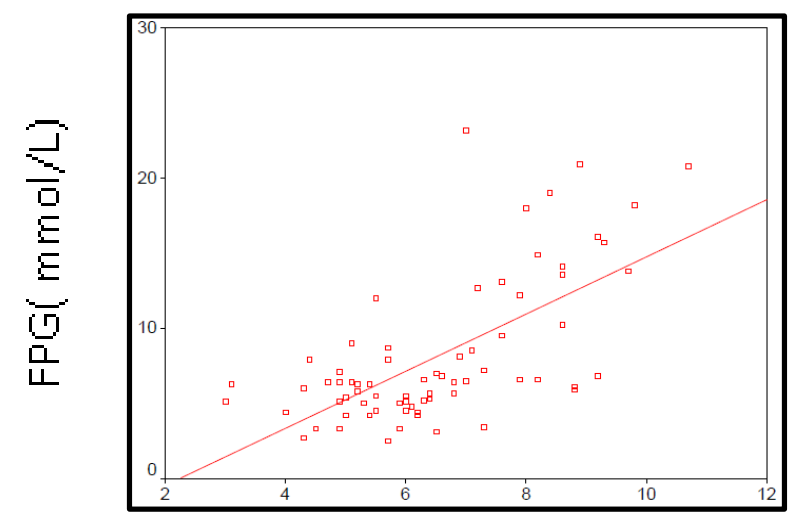

$\mathrm{HbA} 1 \mathrm{c} \%$

$r=0.654 \quad p=0.0001$

Figure(1) Correlation between FPG and HbA1c.

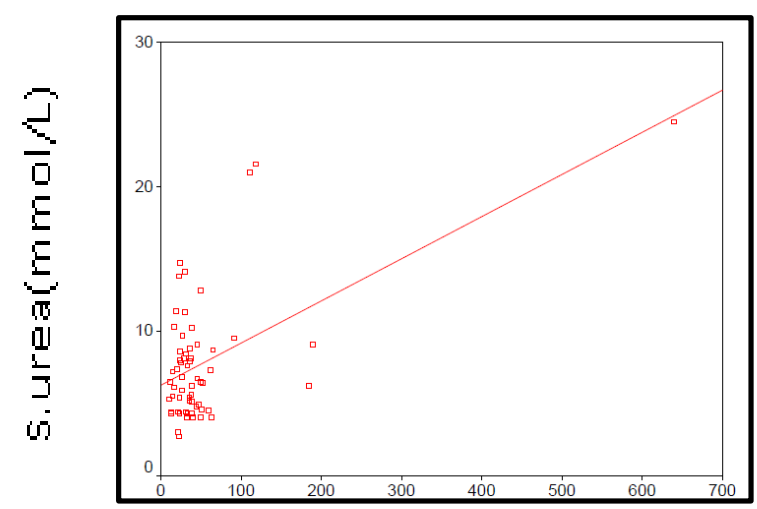

S.creatinine $(\mu \mathrm{mol} / \mathrm{L})$

$$
r=0.644 \quad p=0.0001
$$

Figure(2) Correlation between S.urea and S.creatinine.

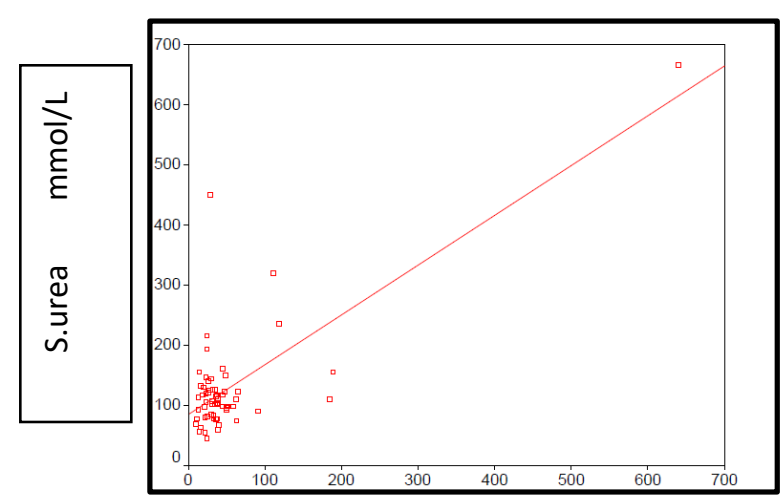

$\mathrm{P} / \mathrm{C}$ ratio $(\mathrm{mg} . / \mathrm{mmol})$

$r=0.563 \quad p=0.0001$

Figure(3) Correlation between $\mathrm{P} / \mathrm{C}$ ratio and S.urea

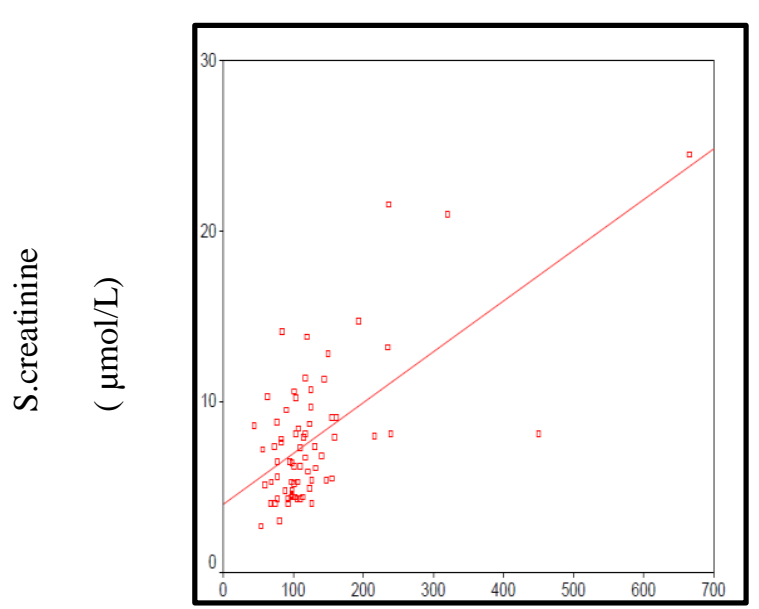

$\mathrm{P} / \mathrm{C}$ ratio $(\mathrm{mg} . / \mathrm{mmol})$

$\mathrm{r}=0.741 \mathrm{p}=0.0001$

Figure(4) Correlation between $\mathrm{P} / \mathrm{C}$ ratio and $\mathrm{S}$. creatinine 


\section{DISCUSSION}

Ischemic heart diseases are one of the major threatings to human life , that affect both quality of life and expectancy of living in addition to their burden on nation economy ${ }^{26}$.

This study made a view on the clinical and biochemical state of seventy one IHD patients who were newly admitted to CCU.

The main difference between those of angina pectoris and those with $\mathrm{AMI}$ was in the higher FPG and $\mathrm{HbA1c}$ in patients with $\mathrm{AMI}$, this is in concordance with Mansour and Wanoose, who demonstrated that regardless of diabetes status, hyperglycemia on arrival for patients presenting with acute coronary syndrome, has been associated with adverse outcomes including death 27

High admission blood glucose levels after AMI are common and are associated with an increased risk of death in subjects with and without diabetes as discussed by Ceriello ${ }^{28}$, and Suleiman et al. demonstrated that while both admission and fasting glucose levels predicted 30-days mortality in non-diabetic patients with AMI, fasting glucose was the better discriminator ${ }^{29}$. Foo et al. found that single serum glucose measurement predicts adverse effect across the whole range of acute coronary syndrome. ${ }^{30}$

Hyperglycemia may multiply the risk of atherosclerosis ${ }^{31}$ and this goes with a prospective case-cohort study by Selvin et al, who showed that elevated $\mathrm{HbA}_{1 \mathrm{c}}$ level is an independent risk factor for coronary heart disease in persons with and without diabetes ${ }^{32}$.

On contrary, Hashemi et al, suggested that impaired fasting glucose is not associated with increased risk of coronary atherosclerosis and its prognostic significance as a predictor of subsequent development of atherosclerosis needs to be evaluated in prospective studies ${ }^{33}$. The deteriorated glycemic control playing a role in elevating blood pressure too, and it is part of stress induced hyperglycemia or what is called acute phase hyperglycemia, a state in which the patients get through upon having $\mathrm{AMI}^{34}$.

Diabetic patients in our study had proteinuria due to nephropathy caused by diabetes, which goes with a study by Pugia et al ${ }^{35}$,so the early detection of microalbuminuria in these patients is of ultimate importance to prevent further deterioration in renal performance ${ }^{36}$.

The detection of microalbuminuria can be done with different methods, some are semi quantitative method like the strips of Micral test which is acceptable up to a concentration of $100 \mathrm{mg} / \mathrm{L}$, but the accuracy of quantitative immunoassay method is justified by high sensitivity, specificity and stability, rapid determination and wide measurement range, ${ }^{37,38}$.

The glycated hemoglobin in this study is correlated to FPG, a finding which goes with other studies ${ }^{39}$, a meta-analysis by Viroj, showed that glycated hemoglobin is correlated to FPG and a poor correlation might be due to the high prevalence of hemoglobin disorder ${ }^{40}$.

The positive correlation between serum urea and serum creatinine is in agreement with other finding by Morgan et al ${ }^{41}$. Elevated serum creatinine has been associated with increased mortality in hypertensive persons. Upper normal serum creatinine concentration is a marker for increased risk of cerebrovascular disease in both normotensive and hypertensive subjects ${ }^{42}$.

In conclusion most of patients with IHD have DM and /or hypertension. IHD patients have badly controlled hyperglycemia and some degree of renal impairment.

There is a significant differences between patients $\mathrm{AMI}$ and those with unstable angina pectoris in regard to glycemic control, FPG is significantly higher in patients with AMI .We recommended stringent monitor of glycemic control in IHD patients. S.urea and S.creatinine should be followed in IHD patients as elevation in these parameters is expected. Protein / creatinine ratio and/or microalbuminuria may be introduced in the list of biochemical tests requested for IHD patients.

Acknowledgement Authors gratefully thank the staff of (CCU) and the staff of biochemistry laboratory in Ibn-Sina teaching hospital for their collaboration . 


\section{REFERENCES}

1. Merck \& Co. Occlusive Peripheral Arterial HealthHandbook.2012.en.wikipedia.org/wiki/lsch emia

2.Sims N R, Muyderman $H$. Mitochondria, oxidative metabolism and cell death in stroke, Biochimica et Biophysica Acta 2010;1802(1): 8091.

3.World Health Organization : Department of Health Statistics and Informatics in the Information, Evidence and Research Cluster. The global burden of disease 2004 update. 2004 Geneva: WHO.

4. Myocardial infarction From the free encyclopedia.2012

en.wikipedia.org/wiki/Myocardial_infarction

5. Erhardt L, Herlitz J, Bossaert L. Task force on the management of chest pain. Eur Heart $\mathrm{J}$ 2002;23 (15): 1153-76.

6.Sharma S, Kortas C.Hypertension. 2006 http://www.emedicine.com

7.Donnelly R, Davis KR .Type 2 diabetes and atherosclerosis. Diabetes, obesity and metabolism 2000; (suppl) $2: 521-530$.

8. Gill GV. Practical management of diabetes in tropics. $\quad$ practical diabetes digest 1990;1 (3): 23-26

9. Femmie de veg, Deckker Jm, Tager A, Heinken E, Kostense PJ, Stehouwar CDA. Relation of impaired fasting and post load glucose with incident type 2 diabetes mellitus in a Dutch population the Hoorn study. JAMA 2001;235: 2109-2113.

10. American Diabetes Association (ADA). Standards of Medical Care in Diabetes. Diabetes care 2011; 34: S11-S61.

11. Goddard J, Turner A N, Cumming A D, and Stewart L $\mathrm{H}$ Kidney and urinary tract disease. In :Boon A N, Colledge N R, Wolker B R, Hunter J A .Davidson's principle and practice of medicine , $20^{\text {th }}$ ed.,Churchill,Livingstone, USA, 2006. pp.: 460-61.

12. Justesen, $T$, Petersen J, Ekbom $P$, Damm $P$, Mathiesen E. Albumin-to-creatinine ratio in random urine samples might replace 24-h urine collections in screening for micro- and macroalbuminuria in pregnant woman with type 1 diabetes. Diabetes care 2006;29(4): 924-925.
13. Abid O, Sun $Q$, Sugimoto $K$, Mercan $D$, Vincent JL. Predictive value of microalbuminuria in medical ICU patients: results of a pilot study. Chest 2001;120 (6): 1984-8.

14. Salomaa V. Old and new diagnostic criteria for acute myocardial infarction. Eur Heart $J$ 2006;26:1719-25.

15. Teitz NW, Burtis CA, Ashwood ER. text book of clinical chemistry $6^{\text {th }}$ ed., Saunders, philadrl Phia, USA, 1994. PP 700, 958-965.

16. Fawcett JK, Scott JE. A rapid and precise method for the determination of urea. $J$ clin path 1960;13: 156-9.

17. Spencer K S. Analytical reviews in clinical biochemistry, the estimation of creatinine. Ann Clin biochem 1986;1: 1-25.

18. Baumgart $R$, France $M W$, UaConaill $D$, Muranaghan S ,Pereira M, Drury MI.(1980). An assessment of a micro column chromatographic method for the measurement of hemoglobin A1. Ann Clin Biochem 17:101-104.

19. Little $\underline{R}$ R. and Roberts W. L. A Review of Variant Hemoglobins Interfering with Hemoglobin A1c Measurement. J Diabetes Sci Technol. 2009; 3(3): 446-451.

20. Mitchell H, Rosner W, Kline Bolton. Renal Function Testing in : Core curriculum in nephrology. American Journal of Kidney Diseases 2006; 47 ( 1) : 174-183

21. Rose B D. Pathophysiology of renal disease, $2^{\text {nd }}$ ed, McGraw- Hill, New York ,1987 p :11

22. Singh A. and Satchel S.C. Microalbuminuria: causes and implications .Pediatr Nephrol. 2011; Nov; 26(11): 1957-1965.

23. Lamb E, Mackanzie F, Stevens P. How should proteinuria be detected and measured? Annals of Clinical Biochemistry. 2009; Vol 46, Issue 3. page(s): 205-217

24. Harrington D, D'Agostino R B, Gatsonis C, et al. New Guidelines for Statistical Reporting in the Journal. N Engl J Med 2019; 381:285-286

25. Gambale E Romano R. Statistics and Medicine: the Indispensable Know-How of the Researcher. Transl Med UniSa. 2013; 5: 28-31

26. Sagmeister M, Gessner U, Oggier $W$, Horisberger B, Gutzwillert F. An economic analysis of ischemic heart disease in Switzerland. Eur Heart J 1997;18: 1102-9 
27. Mansour A , Wanoose H. Acute Phase Hyperglycemia among Patients Hospitalized with Acute Coronary Syndrome: Prevalence and prognostic significance. Oman Med J 2011; 26(2): 85-90

28. Ceriello A. Acute hyperglycaemia: a 'new' risk factor during myocardial infarction. Eur Heart $\mathrm{J}$ 2005; 26(4):328-31

29. Suleiman $M$, Hammerman $H$, Boulos $M$, Kapeliovich MR, Suleiman A, Agmon Y. Fasting glucose is an important independent risk factor for 30-day mortality in patients with acute myocardial infarction: a prospective study. Circulation 2005; 111(6):754-760.

30. Foo K, Cooper J, Deaner A, Knight C, Suliman A, Ranjadayalan K. A single serum glucose measurement predicts adverse outcomes across the whole range of acute coronary syndromes. Heart 2003;89(5):512516.

31. Metelko Z, Pavlic-Renar I, Babic Z. Diabetes mellitus and atherosclerosis. Diabetologica Croatica 2000; $29: 9-18$.

32. Selvin E , Coresh J, GoldenS H , Brancati F L, Folsom A R, Steffes M W. Glycemic control and coronary heart disease risk in persons with and without diabetes Arch Intern Med 2005; 165(16):1910-1916.

33. Hashemi $M$, Taheri $H$, Amiri $N$, Yavari $M$, Shaigannia I, Moghadas L. Is impaired fasting glucose associated with increased risk of coronary atherosclerosis? Acta Medica Iranica 2008;46(1): 38-42.

34. Mullin B, Ennis C, Fee H, Young I, McCance D. Protective effects of ascorbic acid on arterial hemodynamics during acute hyperglycemia. Am J Physiol Heart Circ Physiol 2004;287: H1262H1268.

35. Pugia M J, Wallace J F, Lott J A, Sommer R . Albuminuria and proteinuria in hospitalized patients as measured by quantitative and dipstick methods. Journal of Clinical Laboratory Analysis 2001; 15 (5): 295-300 .

36. Sacks DB, Bruns DE, Goldstein DE, Maclaren NK , Donald JM, Parrott M. Guidelines and recommendations for Laboratory analysis in the diagnosis and management of diabetes mellitus. Clin Chem 2002; 48: 436-72.
37. Ueda H. Sensitive noncompetitive measurement of small molecules by open sandwich immunoassay. YakugakuZasshi 2007;127(1):71-80.

38. Zhao Q, Lin $\mathrm{H}$, Zhang $\mathrm{F}$. Time-resolved fluoroimmunoassay of microalbuminuria. Zhongguo Yi Xue Ke Xue Yuan Xue Bao. 1994; 16(3): 232-8.

39. Sacks D B. Correlation between Hemoglobin A1c (HbA1c) and Average Blood Glucose: Can $\mathrm{HbA} 1 \mathrm{c}$ be reported as estimated blood glucose concentration? J Diabetes Sci Technol 2007;1(6):801-803

40. Wiwanitkit, Viroj. Correlation Between Hemoglobin A1C Level and Fasting Blood Glucose Level: a Summary on the Reports in the Setting with High Prevalence of Hemoglobin Disorder. Acta Facultatis Medicae Naissensis. 2012;29(2): 89-92.

41. Morgan DB, Carver ME, Payne RB. Plasma creatinine and urea: creatinine ratio in patients with raised plasma urea. $\mathrm{Br}$ Med J 1977;2 (6092): 929-32.

42. Wannamethee SG, Shaper AG, Perry IJ. Serum Creatinine Concentration and Risk of Cardiovascular Disease .Stroke 1997;28: 557563 